Asian Review of Social Sciences

ISSN: 2249-6319 Vol.7 No.2, 2018, pp.84-89

(C) The Research Publication, www.trp.org.in

\title{
Food Habits of Adolescent Girls and their Nutritional Status in Select Areas of Coimbatore, Tamil Nadu
}

\author{
M. Valarmathi ${ }^{1}$ and R. Srisiva ${ }^{2}$ \\ ${ }^{1}$ Research Scholar, ${ }^{2}$ Associate Professor, Department of Social Work, \\ Sree Saraswathi Thyagaraja College, Pollachi, Tamil Nadu, India \\ E-Mail: valarmravi@gmail.com,ssranga_21@yahoo.co.in
}

\begin{abstract}
This paper is based on the Pilot Study conducted by the Research Scholar in the four areas - Devangapet, Gandhi Park, Periyar Nagar and Venkatiapuram that comes under the jurisdiction of $11^{\text {th }}$ Project of ICDS at Coimbatore, Tamil Nadu. The paper presents the details of analysis of data collected by administering Interview Schedule to 110 adolescent girls who come to the ICDS Center for periodical meetings. This paper deals with 15 aspects related to Personal Profile of the Respondents, their food habits - snacks intake pattern, Breakfast Intake Pattern, Lunch Intake Pattern and examines the Nutrition Awareness of Respondents in respect to Recommended Dietary Allowance by WHO standards, Assessment of Nutritional Awareness Status and the Reasons for Skipping Breakfast. The study employed application of descriptive statistics such as Mean, Standard Deviation, Correlation, and Factor Analysis. The paper begins with describing the Need and Importance of the Study, Objectives of the Study followed by portrayal of major analysis of data and reports the major findings of the study.
\end{abstract}

Keywords: Malnutrition, Nutrition, and BMI

\section{INTRODUCTION}

This study titled "Food Habits of Adolescent Girls and their Nutritional impact in select areas of Coimbatore District, Tami Nadu" was conducted by the Research Scholar in the four areas - Devangapet, Gandhi Park, Periyar Nagar and Venkatiapuram of the Coimbatore District that fall under the jurisdiction of the $11^{\text {th }}$ ICDS Project in Coimbatore. In all, 110 adolescent girls who reported to the periodical meetings held at the ICDS Center were covered [1].

\section{NEED AND IMPORTANCE OF THE STUDY}

The adage "Healthy body in a h ealthy mind" is possible only when there is proper intake of food at regular interval in the morning, afternoon and night. The Food Habits of adolescent girls are matter of serious concern among the Health Professionals, Child Development Project Administrators, Sociologists, Social Workers, Central and State Government Departments who are in charge of Public Health [2].

World Health Organization in its report on "Adolescent Nutrition: A Review Situation in Select South-Eastern Countries" states:

"Poor nutrition starts before birth, and generally continues into adolescence and adult life and can span generations.
Chronically malnourished girls are more likely to remain undernourished during adolescence and adulthood, and when pregnant, are more likely to deliver low birth-weight babies".

\section{- From Executive Summary}

The Child Health Project Administrators of the ICDS in particular and other related field personnel in general strive for prevention of malnutrition and promotion of healthy food habits among the adolescents girls. Sociologists are much concerned with the deterioration of health standards and unhealthy changes in food habits like increasing fast food consumption.

The Social Workers who are professionally qualified and those who render voluntary service devote considerable time and attention to mitigate the harmful effects of unhealthy food habits and issues related to malnutrition [3].

The Central and State Government Departments in charge of Public Health set their policies related to health and implement several schemes such as nutritional support schemes for prevention of malnutrition.

\section{OBJECTIVES OF THE STUDY}

The objectives of the study are

1. To describe the profile of adolescent girls selected for the study in terms of 16 related demographic variables.

2. To present the details of prevailing food habits of adolescent girls.

3. To find out the Nutritional Awareness among the respondents of the study.

4. To give a picture of assessment of Nutritional Status of the respondents.

\section{EXPLAINING THE TOOL OF DATA COLLECTION TO THE RESPONDENTS}

The Researcher conducted a meeting with the respondents Adolescent Girls regarding the various questions in the questionnaire. A photograph of a meeting is shown below. 


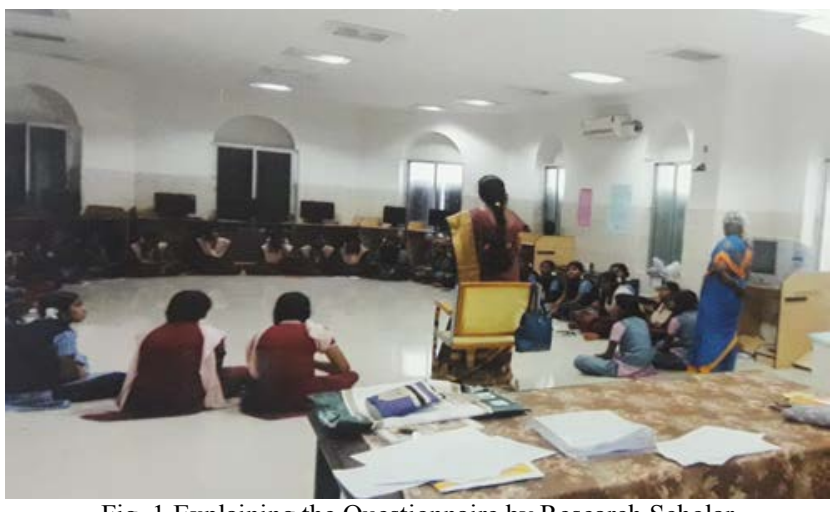

Fig. 1 Explaining the Questionnaire by Research Scholar

\section{PROFILE OF THE RESPONDENTS}

The Profile of Respondents contains 15 related demographic variables. The details in respect to the demographic data are presented in two tables. Table I presents the details in respect to 7 variables and the table two presents the details of the rest 9 variables.

\section{A. Profile of Respondents: An Overview}

In the following an overview of data on the 16 demographic variables is given.

\section{Locale}

The respondents of the study hail from the four locations under the jurisdiction of the $11^{\text {th }}$ Project in Coimbatore. Locale wise 110 respondents selected for this study are Devangapet 14, Gandhi park 3, Periyar Nagar 53 and Venkatiapuram 40.

\section{Age}

The adolescent girls selected in the study ranged from 13 19 years. The average age of the respondents was 15.38 years and the calculated Standard Deviation worked out to 3.63 years. This means the data points are close to the mean.

\section{Education}

The Educational qualifications of the respondents in this study covered students from VIII standard to Second Year of Under-Graduation. The majority of respondents (50.2 per cent) were studying in their X standard followed by 20 per cent each in the VIII and XI standards respectively.

\section{Family Type}

Respondents from the Nuclear Family composition were 91 out of 110 (82.7 per cent) and that of Joint Family 19 (17.3 per cent). This is indicative of the demographic trend of Nuclear Families in the urban area.

\section{BMI}

The Body Mass Index is a measure that takes into account an individual's weight relative to his / her height. The analysis of the data in respect to Locale and BMI of the respondents revealed that 66 out of $110 \mathrm{r}$ espondents had Normal BMI. 29 ou t of 66 respondents under the Normal category were from Venkatiapuram followed by 27 under Periyar Nagar, 8 from Devangapaet and 2 from Gandhi Park. The incidence of respondents coming under 'Thin' category was from two - Periyar Nagar 17 and Venkatiapuram 2. Of the 22 reported case of Overweight 9 were from Venkatiapuram, 7 from Periyarnagar, 5 from Devangapet and 1 from Gandhi Park. Only 3 respondents, 2 under Gandhi Park and 1 under Devangapet were Obese.

Correlation analysis between the family type and BMI showed statistical significance at 5 per cent level of significance (Pearson's r $0.045<$ than critical value 0.05 ). Monthly Income wise BMI status showed majority of respondents 30 out of 44 had non- normal BMI. Correlation analysis showed statistical significance at 5 per cent level of significance (Pearson's r $0.045<$ than critical value 0.05 ).

\section{Family Size}

The Family Size is a factor that indicates family-member density, which in this study ranged from three members to that of 9 members. Only 3 respondents' family had a low 3 member family size followed by an identical 47 respondents' family with a s ize of 3-5 members and 5-7 members. The incidence of highest family size of 9 members was reported from $11 \mathrm{r}$ espondents' families. Correlation analysis showed that the calculated Pearson's $r$ 0.000 was $<$ than the critical value of $p 0.01$. The result is statistically significant at 1 per cent level of significance.

\section{Monthly Family Income}

The Monthly Family Income ranged from Rs 5000 to that of Rs 25000 and is presented by the following bar diagram. The majority of respondents (56 out of 110 respondents 50.9 per cent) family monthly income was in the lowest range of Rs 5000 - Rs 10,000.

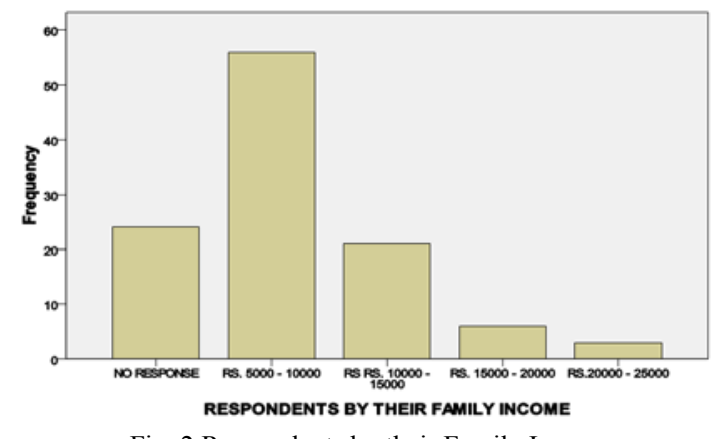

Fig. 2 Respondents by their Family Income

\section{Domicile Status}

The Domicile Status of respondents described the years of living of the respondents. 77 out of 110 respondents ( 70 Per Cent) were living there for more than 10 years, A little over one-tenth (10.9 per cent) of respondents were living between 5 and 10 years and nearly one-fifth 19.1 per cent) were living there for less than 5 years. 
TABLE I PROFILE OF RESPONDENTS

\begin{tabular}{|c|c|c|c|}
\hline S. No. & Aspects of Profile & Frequency & Statistical Measure \\
\hline 1 & $\begin{array}{l}\text { Locale } \\
\text { Devangapet } \\
\text { Gandhi Park } \\
\text { Periyar Nagar } \\
\text { Venkatiapuram }\end{array}$ & $\begin{array}{c}14 \\
3 \\
53 \\
40\end{array}$ & $\begin{array}{l}\text { 12.7 Per Cent } \\
\text { 2.7 Per Cent } \\
\text { 48.2 Per Cent } \\
\text { 36.4 Per Cent }\end{array}$ \\
\hline 2 & $\begin{array}{l}\text { Age-Group } \\
13-15 \text { Years } \\
15-17 \text { Years } \\
17-19 \text { Years } \\
19-21 \text { Years }\end{array}$ & $\begin{array}{c}35 \\
64 \\
10 \\
1\end{array}$ & $\begin{array}{c}\text { Average: } 15.58 \text { Years } \\
\text { Standard } \\
\text { Deviation: } 3.63 \text { Years }\end{array}$ \\
\hline 3 & $\begin{array}{l}\text { Education } \\
\text { Below X Standard } \\
\text { X Standard } \\
\text { XI Standard } \\
\text { XII Standard } \\
\text { UG I Year } \\
\text { UG II Year } \\
\end{array}$ & $\begin{array}{l}22 \\
57 \\
22 \\
3 \\
2 \\
1\end{array}$ & $\begin{array}{l}\text { 20.0 Per Cent } \\
\text { 51.8 Per Cent } \\
\text { 20.0 Per Cent } \\
\text { 2.7 Per Cent } \\
\text { 1.8 Per Cent } \\
\text { 0.9 Per Cent }\end{array}$ \\
\hline 4 & $\begin{array}{l}\text { Family Type } \\
\text { Joint Family } \\
\text { Nuclear Family }\end{array}$ & $\begin{array}{l}19 \\
91\end{array}$ & $\begin{array}{l}\text { 17.3 Per Cent } \\
\text { 82.7 Per Cent }\end{array}$ \\
\hline 5 & $\begin{array}{l}\text { BMI } \\
15 \text { Thin } \\
\text { 16-21 Normal } \\
\text { 22-27 Over Weight } \\
\text { 28-30 Obese }\end{array}$ & $\begin{array}{c}19 \\
66 \\
22 \\
3\end{array}$ & $\begin{array}{l}\text { 17.3 Per Cent } \\
\text { 60.0 Per Cent } \\
\text { 20.0 Per Cent } \\
\text { 2.7 Per Cent }\end{array}$ \\
\hline 6 & $\begin{array}{l}\text { Family Size } \\
\text { 1-3 Members } \\
\text { 3-5 Members } \\
\text { 5-7 Members } \\
\text { 7-9 Members } \\
\text { No Response }\end{array}$ & $\begin{array}{c}3 \\
47 \\
47 \\
11 \\
2\end{array}$ & $\begin{array}{l}\text { 2.7 Per Cent } \\
\text { 42.7 Per Cent } \\
\text { 42.7 Per Cent } \\
\text { 10.0 Per Cent } \\
\text { 1.8 Per cent }\end{array}$ \\
\hline 7 & $\begin{array}{l}\text { Monthly Family Income } \\
\text { Rs } 5000-10000 \\
\text { Rs } 10000-15000 \\
\text { Rs } 15000-20000 \\
\text { Rs } 20000-25000 \\
\text { No Response } \\
\end{array}$ & $\begin{array}{c}56 \\
21 \\
22 \\
3 \\
8\end{array}$ & $\begin{array}{l}\text { 50.9 Per Cent } \\
\text { 19.1 Per Cent } \\
\text { 20.0 Per Cent } \\
\text { 2.7 Per Cent } \\
\text { 7.27 Per cent }\end{array}$ \\
\hline 8 & $\begin{array}{l}\text { Domicile Status } \\
0-5 \text { Years } \\
5-10 \text { Years } \\
10-15 \text { Years } \\
15-20 \text { Years } \\
\end{array}$ & $\begin{array}{l}21 \\
12 \\
32 \\
45\end{array}$ & $\begin{array}{l}\text { 19.1 Per Cent } \\
\text { 10.9 Per Cent } \\
\text { 29.1 Per Cent } \\
\text { 40.9 Per Cent }\end{array}$ \\
\hline 9 & $\begin{array}{l}\text { Parent's Occupational Status } \\
\text { Only Father Earning } \\
\text { Only Mother Earning } \\
\text { Both Parents Earning } \\
\end{array}$ & $\begin{array}{l}39 \\
16 \\
55\end{array}$ & $\begin{array}{l}\text { 35.5 Per Cent } \\
\text { 14.5 Per Cent } \\
\text { 50.0 Per Cent }\end{array}$ \\
\hline 10 & $\begin{array}{l}\text { Nativity } \\
\text { Urban } \\
\text { Rural } \\
\text { No Response }\end{array}$ & $\begin{array}{c}96 \\
13 \\
1\end{array}$ & $\begin{array}{c}\text { 87.3 Per Cent } \\
\text { 11.8 Per Cent } \\
\text { 0.9 Per Cent }\end{array}$ \\
\hline 11 & $\begin{array}{l}\text { Food Habits Profile } \\
\text { Take Breakfast daily } \\
\text { Take Breakfast once in two days } \\
\text { Take Breakfast on Sundays and } \\
\text { Holidays } \\
\text { Do not take Break Fast } \\
\text { No Response }\end{array}$ & $\begin{array}{l}55 \\
20 \\
17 \\
17 \\
1\end{array}$ & $\begin{array}{c}\text { 50.0 Per Cent } \\
\text { 18.2 Per Cent } \\
\text { 15.5 Per Cent } \\
\text { 15.5 Per Cent } \\
\text { 0.9 Per Cent }\end{array}$ \\
\hline 12 & $\begin{array}{l}\text { Food Source } \\
\text { Home-made food } \\
\text { Outside food }\end{array}$ & $\begin{array}{l}97 \\
13\end{array}$ & $\begin{array}{l}\text { 88.2 Per Cent } \\
\text { 11.8 Per Cent }\end{array}$ \\
\hline
\end{tabular}




\begin{tabular}{|c|c|c|c|}
\hline 13 & $\begin{array}{l}\text { Food Preference } \\
\text { Fast Food } \\
\text { Traditional Food } \\
\text { No Response }\end{array}$ & $\begin{array}{c}31 \\
78 \\
1\end{array}$ & $\begin{array}{l}\text { 28.2 Per Cent } \\
\text { 70.9 Per Cent } \\
\text { 0.9 Per Cent }\end{array}$ \\
\hline 14 & $\begin{array}{l}\text { Respondents Occupational Status } \\
\text { Employed } \\
\text { Not Employed }\end{array}$ & $\begin{array}{c}2 \\
108\end{array}$ & $\begin{array}{l}\text { 1.8 Per Cent } \\
\text { 98.2 Per Cent }\end{array}$ \\
\hline 15 & $\begin{array}{l}\text { Respondents Caste Status * } \\
\text { ST } \\
\text { SC } \\
\text { MBC } \\
\text { BC } \\
\text { General Turn includes the remaining } \\
\text { and all the above categories }\end{array}$ & $\begin{array}{c}1 \\
19 \\
22 \\
33 \\
35\end{array}$ & $\begin{array}{c}\text { 0.90 Per Cent } \\
\text { 17.27 Per Cent } \\
\text { 20.0 Per cent } \\
\text { 30.0 Per Cent } \\
\text { 31.8 Per Cent }\end{array}$ \\
\hline
\end{tabular}

\section{Nativity}

The data on Nativity indicated 96 out of 110 respondents (87.3 per cent) were from urban area and the rest 14 were from the rural area.

\section{Food Profile}

Food Profile included data on those who take Breakfast daily and those who are irregular or do not take Breakfast. Half the respondents (55 out of $110-50$ per cent) took daily breakfast and the rest (55 out of $110-50$ per cent) were either irregular or did not take any breakfast.

\section{Food Source}

The responses in respect to Food Source indicated that 97 out of $110 \mathrm{r}$ espondents ( 88.18 per cent) had home-made food and the rest 13 had food from outside.

\section{Food Preference}

Information on food preference of the respondents indicated majority of 68 ( 61.81 per cent) preferred traditional food and the rest 31 preferred fast food. Of the 31 respondents who indicated preference for fast food 30 (96.87 per cent) were from the urban area. Further analysis showed that the calculated value of Pearson's Correlation statistic $r$ value $p$
0.023 was less than the critical value of $\mathrm{r} 0.05$. This means the result is statistically significant at 96 per cent level of confidence. This is rather indicative of the trend that Fast Food is a prime attraction in the urban area.

\section{Respondents' Occupational Status}

108 out of 110 respondents were not employed as all of them were students.

\section{Respondents’ Caste Status}

Caste Status of respondents were: ST 1 (0.90 Per Cent), SC 19 (17.27 Per Cent), MBC 22 (20.0 Per Cent), BC 33 (30 Per Cent) and the remaining are classified as General Turn class. The General Turn class includes the remaining communities as well as members from the above categories 35 (31.18 Per Cent). The community-wise data has been picked up from the collected data as per the Tamil Nadu state classification of communities [4].

\section{FACTOR ANALYSIS}

The Researcher carried out factor analysis for food habits of respondents for snack intake pattern, breakfast intake pattern and lunch intake pattern.

TABle Ii Total Variance Explained For Respondents' Intake Of SNACKs Pattern

\begin{tabular}{|l|c|c|c|c|c|c|}
\hline \multirow{2}{*}{ Component } & \multicolumn{3}{|c|}{ Initial Eigenvalues } & \multicolumn{3}{c|}{ Extraction Sums of Squared Loadings } \\
\cline { 2 - 7 } & Total & \% of Variance & Cumulative \% & Total & \% of Variance & Cumulative \% \\
\hline Ready Food & 1.963 & 19.630 & 19.630 & 1.963 & 19.630 & 19.630 \\
\hline Bakery Food & 1.630 & 16.296 & 35.927 & 1.630 & 16.296 & 35.927 \\
\hline Fast Food & 1.369 & 13.687 & 49.613 & 1.369 & 13.687 & 49.613 \\
\hline Fried Food & 1.125 & 11.245 & 60.858 & 1.125 & 11.245 & 60.858 \\
\hline Pulses & .910 & 9.096 & 69.955 & - & - & - \\
\hline Sweets & .813 & 8.134 & 78.088 & - & - & - \\
\hline Cereals & .747 & 7.467 & 85.555 & - & - & - \\
\hline Eggs & .668 & 6.676 & 92.231 & - & - & - \\
\hline Milk & .482 & 4.823 & 97.053 & - & - & - \\
\hline Porridge & .295 & 2.947 & 100.000 & - & - & - \\
\hline
\end{tabular}

Extraction Method: Principal Component Analysis. Cronbach's Alpha 0.515 
Table II shows the total variance explained by the 10 items of snacks. Principal Component Analysis extracted four components - 'Ready Food', 'Bakery Food', 'Fast Food' and 'Fried Food'. These four snacks item together accounted for 60.58 per cent of variance in the study. The factor 'Ready Food' accounted for 19.63 per cent of variance. The factor 'Bakery Food' accounted for 16.29 per cent, 'Fast Food' accounted for 13.68 per cent of variance and 'Fried Food' accounted for 11.24 per cent of variance. [5].

It is noteworthy to mention here that healthy foods like Pulses, Cereals, Eggs and Milk accounted for less than 10 per cent each of the remaining variance. Reliability for this scale worked out to Cronchbach's Alpha 0. 515 which means moderate internal consistency of responses.

Table II shows the results of factor analysis for 10 breakfast items that accounted for the total variance in the study. Principal Component Analysis extracted four components Idly, Dosa, Pongal and Upma. These together accounted for 57.56 per cent of the study.

The breakfast item Idly accounted for 20.25 per cent of variance, Dosa for 14.37 per cent, Pongal 12.82 per cent and Upma 10.10 per cent. Non-South Indian dishes like Oats, Sandwich, Buns and Ice-creams each accounted for less than 10 per cent of variance.

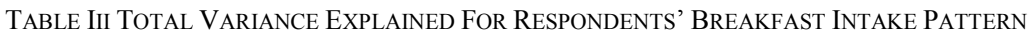

\begin{tabular}{|l|c|c|c|c|c|c|}
\hline \multirow{2}{*}{ Component } & \multicolumn{4}{|c|}{ Initial Eigenvalues } & \multicolumn{3}{c|}{ Extraction Sums of Squared Loadings } \\
\cline { 2 - 7 } & Total & \% of Variance & Cumulative \% & Total & \% of Variance & Cumulative \% \\
\hline Idly & 2.026 & 20.259 & 20.259 & 2.026 & 20.259 & 20.259 \\
\hline Dosa & 1.437 & 14.372 & 34.631 & 1.437 & 14.372 & 34.631 \\
\hline Pongal & 1.283 & 12.828 & 47.459 & 1.283 & 12.828 & 47.459 \\
\hline Upma & 1.010 & 10.101 & 57.560 & 1.010 & 10.101 & 57.560 \\
\hline Chappathis & .993 & 9.928 & 67.488 & & & \\
\hline Pooris & .834 & 8.337 & 75.825 & & & \\
\hline Oats & .759 & 7.587 & 83.413 & & & \\
\hline Sandwitch & .637 & 6.374 & 89.787 & & & \\
\hline Buns & .547 & 5.473 & 95.260 & & & \\
\hline Ice-creams & .474 & 4.740 & 100.000 & & & \\
\hline
\end{tabular}

Extraction Method: Principal Component Analysis. Cronchbach;s Alpha 0.544

Table III shows the total variance of the 8 lunch items. Principal Component Analysis extracted four components Three Course Meal, Chappathis, Chappathis with rice, and variety rice. These together accounted for 64.08 per cent of variance in the study. Three Course Meal accounted for 21.68 per cent followed by Chappathis 15.80 per cent, Chappathis and rice 13.86 per cent and variety rice 12.70 per cent.

TABle IV TOTAL VARIANCE EXPLAINED For RESPONDENTS’ LUNCH INTAKE PATTERN

\begin{tabular}{|l|c|c|c|c|c|c|}
\hline \multirow{2}{*}{ Component } & \multicolumn{4}{|c|}{ Initial Eigenvalues } & \multicolumn{3}{c|}{ Extraction Sums of Squared Loadings } \\
\cline { 2 - 7 } & Total & \% of Variance & Cumulative \% & Total & \% of Variance & Cumulative \% \\
\hline $\begin{array}{l}\text { Three course } \\
\text { Meals }\end{array}$ & 1.735 & 21.682 & 21.682 & 1.735 & 21.682 & 21.682 \\
\hline Chappathis & 1.264 & 15.802 & 37.484 & 1.264 & 15.802 & 37.484 \\
\hline $\begin{array}{l}\text { Chappathis } \\
\text { and Rice }\end{array}$ & 1.109 & 13.863 & 51.347 & 1.109 & 13.863 & 51.347 \\
\hline Variety Rice & 1.016 & 12.700 & 64.048 & 1.016 & 12.700 & 64.048 \\
\hline Curd Rice & .874 & 10.930 & 74.977 & & & \\
\hline One type rice & .756 & 9.449 & 84.427 & & & \\
\hline Mini Lunch & .659 & 8.237 & 92.664 & & & \\
\hline Tiffin only & .587 & 7.336 & 100.000 & & & \\
\hline
\end{tabular}

Extraction Method: Principal Component Analysis. Cronchbach's Alpha 0.444

\section{ASSESSMENT OF NUTRITIONAL STATUS}

The Researcher carried out the Nutritional Assessment of the respondents by examining factors like decreased intake of food, weight loss, Psychological stress and the BMI. Decreased Food Intake question was assessed by assigning ' 0 ' points for severe decrease, 1 point for Moderate Decrease, 2 points for No increase. Weight loss was 
measured by assigning ' 0 ' point for weight loss greater than 3 kilograms, 1 point for do not know, 2 points for weight loss between 1 and 3 kilograms and 3 points for No weight loss. Response of yes for Psychological Stress was assigned ' 0 ' point, and 2 points for response 'No'. BMI was assessed by assigning 0-4 points Malnutrition, 4-8 points for Risk of Malnutrition and 8-10 points for Normal Nutrition. The results of Nutritional Assessment Status indicated 15 respondents were having malnutrition, 58 were under the risk of malnutrition and 17 were having Normal Nutrition.

\section{FINDINGS}

This section presents the findings of the study in the light of objectives of the study.

1. Average age of the respondents was 15.38 years.

2. More than half the respondents were studying in $X$ standard.

3. More than 80 per cent of respondents were from the Nuclear Families.

4. BMI showed an encouraging trend of 60 pe $r$ cent of respondents in the Normal BMI category.

5. More than half the respondents were from families having the lowest range of Monthly Family Income of Rs 5000-Rs 10000.

6. More than three-fourth of respondents were living there for more than 10 years.

7. More than 80 per cent of respondents were from the urban area.

8. Half the respondents took their breakfast daily and the rest were either irregular in taking breakfast or did not take breakfast at all.

9. Study found an encouraging trend of more than 85 per cent of respondents' food source was 'Home-made food'.

10. Study found a strong preference for 'Traditional Food' among more than 60 per cent of respondents.

11. Except 2 respondents all the rest 108 respondents were not employed.

12. Caste status of respondents represented that 31 Per Cent belonged to the General Turn, followed by BC $30 \mathrm{Per}$ Cent and MBC 20 Per Cent. This has been done to identify respondents based on the state Government's classification.

13. Factor Analysis of Food Habits of respondents showed that snacks made from healthy food items like Pulses, Cereals, Eggs and Milk were not major snack items for the respondents.

14. Traditional Food items of breakfast like 'Idly, Dosa, Pongal and Upma' accounted for 57.56 per cent of variance in the study for 'Breakfast Intake Pattern'.

15. Traditional 'Three course meal, Chappathis and rice accounted for 64 per cent of variance in the study for' Lunch Intake Pattern in the study'.
16. Nutritional Assessment of the respondents found that 15 were in the category of Malnutrition, 58 were under the 'Risk of Malnutrition' and 17 had Normal Nutrition.

\section{SUGGESTIONS}

1. In view of the fact that in the study food habits showed consumption of unhealthy foods like fast food, fried food, etc it is suggested that the ICDS Project Administrators should focus more on educating the need for taking healthy foods and intensify their efforts in augmenting better Supplementary Nutrition Diet for all the adolescents.

2. In view of the finding that half the respondents were either irregular in taking breakfast or do not take breakfast at all it is suggested that Educational Programmes imparting harmful effects of Skipping Breakfast should be undertaken.

\section{CONCLUSION}

This study was conducted by collecting data from 110 adolescent girls in four areas under the jurisdiction of the $11^{\text {th }}$ ICDS Project Centre at Coimbatore. The paper presented the Profile of Respondents in terms of 16 Demographic Variables and described the results of the Analysis of Data in respect to Food Habits of the Adolescents in respect to Snacks Intake Pattern, Breakfast Intake Pattern and Lunch Intake Pattern. Results of the Factor Analysis have been dovetailed. At the end the major findings were reported with viable suggestions for promoting 'Healthy Food Habits' and striving for better Nutrition Status of all the adolescents. It is hoped that this study would be useful for Child Project Administrators of the ICDS.

\section{REFERENCES}

[1] WHO Report. (2006). Adolescent nutrition: a review of the situation in selected South-East Asian Countries. Compiled from Executive Summary, Child and adolescent health and development.

[2] Ashok Kumar, T. (2012). Nutritional Status of Adolescent Girls in Rural Tamil Nadu. Nat.J.Res.Com.Med., 1(1), 01-60.

[3] Varuna Gaikiand Vasant Wagh. (2014, March-April) Nutritional Status of Adolescent Girls from a Selected ZRural District from Central India. Innovative Journal of Medical andsHealth Science 4(2), 90-92.

[4] Anuradha. (2015). Nutritional Security in Tamil Nadu and India: A Comparative Analysis. Int. Journal of Management and Development Studies, 4(4), 402-411. ISSN (Online): 2320-0685. ISSN (Print): 2321-14.

[5] Suda Narayanan. Food Security in India: The Imperatives and its Challenges. Retrieved from http://onlinelibrary.wiley.com/doi/10. 1002/app5.62/full. 